T. Kovaliuk ${ }^{1}$, O. Chaikovska ${ }^{2}$

${ }^{1}$ National Technical University of Ukraine "Igor Sikorsky KPI", Kyiv, Ukraine

${ }^{2}$ Kyiv National University of Culture and Arts, Kyiv, Ukraine

\title{
EDUCATIONAL PROGRAMS AND PROFESSIONAL STANDARDS IN THE IT FIELD AS FACTORS OF DEVELOPMENT OF IT EDUCATION
}

\begin{abstract}
The subject matter of the article is the processes of synthesis of the information and telecommunication network (ITN) for solving applied problems of safety-critical systems (SCS). The goal is to develop a mathematical model for the optimal distribution of applied tasks of safety-critical systems over the ITN nodes. The tasks to be solved are: to formalize the procedure of distribution of applied tasks and SCS software over the ITN nodes; to develop a mathematical model of optimal distribution in order to minimize the cost of network resources; to select an effective algorithm for solving it. The methods used are: alternative-graph approach, mathematical optimization models, methods for solving nonlinear integer programming problems with Boolean variables. The following results were obtained: the task of selecting the ITN optimal structure was formulated according to the alternative-graph model of information processing; in addition to structural characteristics, the requirements for the parameters necessary for performing applied tasks were taken into account while constructing a mathematical model; when minimizing the cost of a computing resource, constraints related to the capabilities for financing the development and operation of the network are taken into account; the costs for organizing additional connections among the network nodes are considered as well. Conclusions. The scientific novelty of the results obtained is as follows: 1) the optimization model of distributing applied tasks over the nodes of the computer network was improved by defining the objective function in order to minimize the costs of both computational and data transmission and the constraints caused by the requirements for the technical and information structure of the network; 2) methods for solving the problems of optimizing the ITN structure on the basis of models of nonlinear Boolean programming by transforming the initial task into a linear form and applying the recession vector method was further developed, which makes obtaining a quasi-optimal solution of the problem in the context of large dimension possible.
\end{abstract}

Keywords : IT-industry; IT-education; professional standard; educational standard; competence.

\section{Introduction}

As of effective date of the new law of Ukraine "On Higher Education" and after approval of the new list of knowledge area and specialties, new stage of Ukrainian Higher Education reforming has begun. Autonomy of the Universities in terms of forming educational content is a main sign of this stage. The Universities independently define educational content in terms of result of education as well as discipline list which would ensure this result. The developing educational content is based on competency approach, requirements of National framework of qualifications and stakeholders (employers). Formalization of stakeholders' requirements is reflected in professional standards. Educational content is defined by educational standards. IT industry requirements are very important for Ukrainian Educational Standards in IT knowledge area as IT is an engine of economic growth of Ukraine, so training future IT professionals is a critical task.

\section{Discussion}

Problem Statement. Modern trends in development of Information Technologies and innovational approaches can be implemented in Ukrainian companies which will support Ukrainian economic growth as long as qualified professionals are available. Ukrainian Higher Educational Institutions provide IT market with 16 thousands graduates annually [1]. More than 60 Ukrainian Universities train specialists in IT area Higher Education scientists develop educational standards in order to meet requirements of IT industry. Still analysis of IT employers' requirements is not considered. Purpose of this article is to contemplate ways to harmonize IT education and IT Professional Standards in terms of formation, development, accumulation, renewal, assessment of IT professionals' qualifications and competencies in accordance with European eCompetence Framework (e-CF) and Ukrainian stakeholders' requirements.

Actuality of research. IT industry requires competent professionals who are ready to successfully start IT career without additional cost from employer's side. Ukrainian Educational IT Standards were developed without consideration of IT industry needs and European e-CF . Necessary system of requirements to training, experience and skills of the workforce was not introduced as well. Thus, development of professional standards based on competence approach, European e-CF and trends in IT education is a critical problem in Ukraine.

Normative documents on content of Higher Education of Ukraine. In order to ensure that higher education quality corresponds to labor market and international institutions' requirements, it is important to define place and role of educational standards in Ukrainian higher education system and their link to professional standards.

Higher Educational Standard is a set of requirements to content and results of educational activities of higher education and scientific institutions by each higher educational level within each discipline. Higher Educational Standards are intended to define and assess quality, content and results of educational activities of higher educational institutions.

Professional standard is a ratified set of requirements to employees' qualification, their 
competencies which are defined by employers. Professional standards are the base for formation of professional qualifications. In accordance to the Law of
Ukraine "On Higher Education" [2] the following normative documents define educational content (Fig. 1) [3].

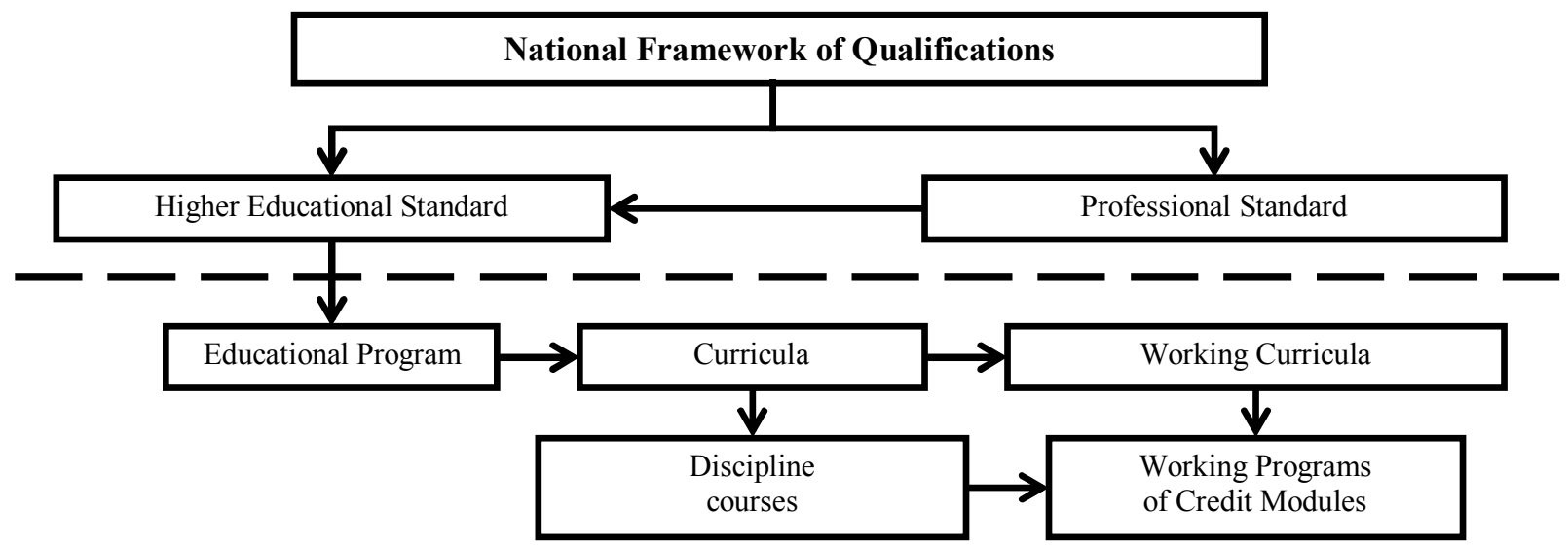

Fig. 1. Normative documents of content of higher education of Ukraine

National Framework of Qualifications (NFQ) is a systematic and structured by competencies description of qualification levels. NFQ is a generalized description of educational results which include clearly-defined criteria of relation to certain qualification. NFQ's qualification levels are described via descriptors which are formulated in terms of results of education based on requirements to knowledge, skills, communicative competency, autonomy, responsibility and general (integral) competency. It is intended to be used by governmental authorities, institutions and organizations which realize state policy in area of education, employment and social labor relations as well as by educational institutions, employers and other legal entities and individuals with purpose of creation, identification, correlation, definition, planning and development of qualifications [4].

Educational program is a system of educational components at respective higher education level within certain discipline. Educational program defines requirements to educational level of individuals who study according to this program, list of educational subjects and logical sequence of the subjects, number of credits ECTS necessary to accomplish this program as well as expected results of education (competencies) which should be obtained by the graduates of respective higher education degree [2].

Program results of education are the complex of knowledge, skills, other competencies obtained by individuals in the process of education as per certain program [2]. It is important to be able to assess and measure those knowledge, skills and competencies.

Educational plan is a document which defines list and amount of normative and selective educational subjects, sequence of their study, form and amount of educational activities, schedule of educational process, summary and control measures [2]. Educational program is developed for each discipline in educational plan. This program includes information about the discipline content and results of education. The normative documents above are the normative base for educational system as per certain subject.
Harmonization of Educational and Professional IT standards in the process of modernization of higher IT education. Professional and Educational standards need to be the elements of united national system of qualifications which should be submitted as complex of interrelated documents providing correlation between professional education and labor market in order to improve quality of training specialists and their competitive ability at local and international labor markets.

Professional standards should not only be based on international standards. International standards can be just one of the resources to create national educational standards in terms of definition of typical tasks, specialized professional and instrumental competencies, basic knowledge and skills. Together with recommendations of Computing Curricula CC2001CC2005/CS2013/SE2014/IT2014/IS2010/CE2016/MSI S2016/CSE2017 of international IT associations and communities ACM, IEEE, AIS, AITP [6 - 14] professional standards in IT industry contribute to harmonization of graduates' qualifications with employers' requirements.

Interrelation between Professional and Educational standards is represented in Fig. 2 below.

Professional standards provide educational sphere with necessary data regarding graduates' professional activity area, objects of this activity, its kinds and tasks, necessary competencies of future professionals. There are the following directions of application of professional IT standards: development of educational standards based on professional standards; development of educational programs with consideration of IT industry requirements; quality evaluation of education in accordance with employers' requirements; prompt update of educational standards based on changes in professional standards.

In accordance to structure and content of industry standards of higher education, Professional standards might be the base to define competencies required for realization of typical tasks of activity and operational functions of graduates with bachelors' and masters' degree. 


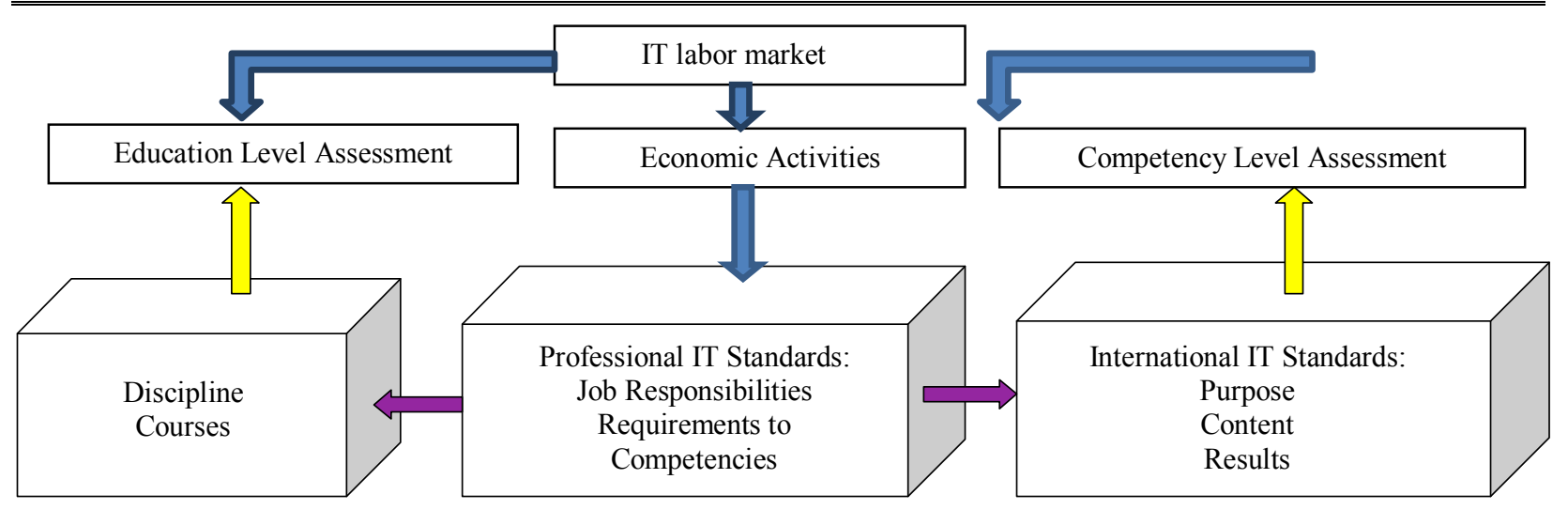

Fig. 2. Interrelation between Professional and Educational IT standards

For example, typical task of activity "Development of functional requirements to projected system" of industry standard of higher education bachelor's degree "Computer science" is inherited from activity task "Defining initial customer's requirements to IS and opportunities of their realization" of Professional standard "Information System Specialist" [15]. Similarly, ability of "Development of requirements and specifications of components in information systems and objects of professional activity" which is defined in industry standard of higher education bachelor's degree "Computer Science" is based on ability to analyze subject area of automation and prepare respective documentation [16].

Requirements to basic knowledge specified in professional standards give opportunity to define list of disciplines in curricula which IT student will obtain. Thus, Professional standard "Information System Specialist" defines such knowledge area as mathematical training, programming, technology and processes of software development, data processing, technical training, and general operational culture. Each of the knowledge area listed above defines detailed study items which will help students to obtain necessary competencies. Using Professional standard basic knowledge list, education stakeholders can define list of study discipline to be included to bachelor's and master's curricula.

Perception of competencies as a result of education in the context of educational standards improves efficiency of the dialogue between employers (as customers of education result) and higher education institutions (as providers of education result). In this regards educational technologies are considered as a way to form competence (via active and interactive teaching methods) and evaluation systems (via involvement employers and professional experts to their development) as a tool to complete the competencies formation.

International IT standards overview. Including accepted in Europe IT courses of study to domestic higher educational system ensures its succession and harmonization with European IT educational programs which is transparent to IT industry, open to qualification and advanced training in terms of Double Degree and Academic Mobility of students, postgraduates and professors. According to international Computing Curricula recommendation, IT education in Ukraine includes the following specialties (table 1) [17].
Table 1. IT Education Specialties

\begin{tabular}{|l|c|l|}
\hline \multicolumn{1}{|c|}{$\begin{array}{c}\text { Knowledge } \\
\text { Area }\end{array}$} & $\begin{array}{c}\text { Specialty } \\
\text { code }\end{array}$ & \multicolumn{1}{|c|}{ Specialty name } \\
\hline \multirow{4}{*}{$\begin{array}{l}\text { 12 Information } \\
\text { Technology }\end{array}$} & 121 & Software Engineering \\
\cline { 2 - 3 } & 122 & Computer Science \\
\cline { 2 - 3 } & 123 & Computer Engineering \\
\cline { 2 - 3 } & 124 & System analysis \\
\cline { 2 - 3 } & 126 & $\begin{array}{l}\text { Information Systems and } \\
\text { Technology }\end{array}$ \\
\hline
\end{tabular}

Structure of educational standard includes the following sections [18]:

1. General characteristic

2. Amount of credits ECTS necessary to obtain respective level of higher education

3. Graduate's competency list

4. Normative content of higher education in terms of results of education

5. Forms of attestation in higher educational institutions

6. Requirements to internal system of higher education quality assurance exist)

7. Requirements of Professional standards (if

8. List of normative documents which are the base for Higher Education Standard

General characteristic of specialty of Ukraine provides description of subject area of activity with definition of study and activity objects, study purpose, theoretical content of subject area, types of professional activity, methods, methodologies and technologies, which should be obtained by graduates of higher education institution, tools and equipment to obtain those knowledge and skills.

Comparative analysis of IT specialties characteristics is represented in table 2.

After detailed discussion regarding comparison of the objects of study and activities and theoretical content of the subject area of education in SE, CS, CE, SA, Cybersecurity, IST, we can say that each IT specialty may declare different opinions regarding systems of teaching, variety of knowledge and skills. 


\section{Table 2. Comparative analysis of activity objects of IT Education Specialties}

\begin{tabular}{|c|c|c|c|}
\hline $\begin{array}{l}\text { Specialty } \\
\text { code }\end{array}$ & $\begin{array}{l}\text { Specialty } \\
\text { name }\end{array}$ & Objects of study and activities & $\begin{array}{l}\text { Theoretical content } \\
\text { of the subject area }\end{array}$ \\
\hline 121 & $\begin{array}{l}\text { Software } \\
\text { Engineering } \\
(\mathrm{SE})\end{array}$ & $\begin{array}{l}\text { Processes, instrumental tools and resources of } \\
\text { software development and support }\end{array}$ & $\begin{array}{l}\text { Basic mathematical, physical, } \\
\text { economical statements regarding } \\
\text { software development and support; } \\
\text { theoretical basis for domain analysis, } \\
\text { modeling, projecting, design, } \\
\text { software support. }\end{array}$ \\
\hline 122 & $\begin{array}{l}\text { Computer } \\
\text { Science } \\
\text { and } \\
\text { Information } \\
\text { Technologies } \\
\text { (CS\&IT) }\end{array}$ & $\begin{array}{l}\text { Mathematical, informational, imitation models of } \\
\text { real phenomenon, objects, systems and processes; } \\
\text { models of knowledge and data submission; models, } \\
\text { methods and technologies of getting, storing, } \\
\text { processing, transmitting and using information; } \\
\text { theory, analysis, building, effectiveness assessment, } \\
\text { realization of algorithms; methods and algorithms } \\
\text { of operational multidimensional and intellectual } \\
\text { data analysis and decision making; high-productive } \\
\text { computing including parallel calculation and vast } \\
\text { data; mathematical, linguistic, informational } \\
\text { provision of automated systems of data processing } \\
\text { and management, pattern and signals recognition } \\
\text { systems, projecting automation systems, decision } \\
\text { support systems, intellectual systems. }\end{array}$ & $\begin{array}{l}\text { Modern models, methods, } \\
\text { algorithms, technologies, processes } \\
\text { and ways of data obtaining, } \\
\text { providing, processing, analysis, } \\
\text { transmission, storage in information } \\
\text { systems; knowledge engineering } \\
\text { technologies; programming and } \\
\text { projecting technologies and } \\
\text { platforms, development and quality } \\
\text { assurance of IT and IS components; } \\
\text { computer graphics methods and data } \\
\text { visualization technologies. }\end{array}$ \\
\hline 123 & $\begin{array}{l}\text { Computer } \\
\text { Engineering } \\
(\mathrm{CE})\end{array}$ & $\begin{array}{l}\text { Programming technical tools of computers and } \\
\text { computer systems of universal and special purpose } \\
\text { including local, global computer networks, Internet, } \\
\text { Internet of Things; Informational processes, } \\
\text { technologies, methods and systems of automatic and } \\
\text { automated design; establishment, production and } \\
\text { operation of programming and technical tools; } \\
\text { methods of information processing including high- } \\
\text { productive, parallel, divided, mobile, web-based, } \\
\text { cloud, energy effective, safe, autonomic, adaptive, } \\
\text { intellectual data, etc. }\end{array}$ & $\begin{array}{l}\text { Concept, principles, programming } \\
\text { and technical methods and } \\
\text { technologies of development, } \\
\text { operation and maintenance of } \\
\text { computer systems and networks, } \\
\text { inbuilt and divided computing. }\end{array}$ \\
\hline 124 & $\begin{array}{l}\text { System } \\
\text { Analysis } \\
(\mathrm{SA})\end{array}$ & $\begin{array}{l}\text { Mathematical methods and information } \\
\text { technologies of analysis, modelling, forecasting, } \\
\text { design and decision making in complex systems of } \\
\text { different nature. }\end{array}$ & $\begin{array}{l}\text { Theory of leading and decision } \\
\text { making, mathematical and computer } \\
\text { modeling, mathematical statistics } \\
\text { and data analysis, operations } \\
\text { research, systems and processes } \\
\text { optimization. }\end{array}$ \\
\hline 125 & Cyber security & $\begin{array}{l}\text { Technologies of information security of } \\
\text { information objects including computer, automated, } \\
\text { telecommunication, information, analytical } \\
\text { systems, information resources and information } \\
\text { technologies, processes of management of } \\
\text { information and cyber security of the objects to be } \\
\text { protected. }\end{array}$ & $\begin{array}{l}\text { Legislative regulatory framework of } \\
\text { Ukraine and requirements of } \\
\text { international standards and practices } \\
\text { in regards of professional activity; } \\
\text { principles of information security } \\
\text { systems design; methods of } \\
\text { information security vulnerabilities } \\
\text { and threats identification, } \\
\text { information security assessment; } \\
\text { methods of analysis and planning } \\
\text { project cyber security solutions. }\end{array}$ \\
\hline 126 & $\begin{array}{l}\text { Information } \\
\text { Systems } \\
\text { \&Technologies } \\
\text { (IST) }\end{array}$ & $\begin{array}{l}\text { Methods of design and operation of information } \\
\text { systems and technologies (IST) in different fields of } \\
\text { economics; methods of IST quality assurance, } \\
\text { reliability, viability, optimization principles, } \\
\text { decisions models and methods in conditions of } \\
\text { uncertainty; development of information } \\
\text { communications, theoretical and applied tools of } \\
\text { design and implementation of intellectual } \\
\text { information technologies. }\end{array}$ & $\begin{array}{l}\text { Concept and principles of higher and } \\
\text { applied mathematics, programming, } \\
\text { computer and mathematical modelling, } \\
\text { intellectual data processing, system } \\
\text { analysis and projecting, information } \\
\text { management, system integration and } \\
\text { administration, IT projects } \\
\text { management, entities architecture and } \\
\text { IT infrastructure. }\end{array}$ \\
\hline
\end{tabular}


There is some overlap within these six fields. Essentially, they exist in subsections of the same area, performing complementary different tasks that fit together.

Opinions of international IT standards developers and curators of scientific methodical council of the Ministry of Education and Science of Ukraine differ from the state and trends of IT Education in USA and in the world and understanding difference between specialties CS, CE, SE, IS, IT. Thus, in Computing Curricula 2005 analysis of interrelation between specialties was done (fig. 3) and place of each of them in IT education system was defined [6].

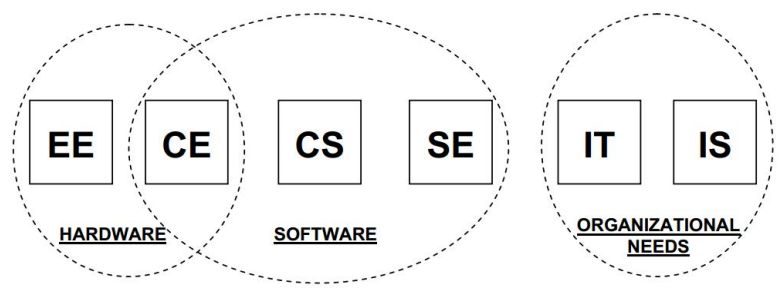

Fig. 3. Interrelation between IT specialties in accordance to Computing Curricula 2005

Analysis of objects of activity, theoretical content, competencies which are defined in standards of IT specialties of Ukraine identifies significant differences with Computing Curricula recommendations. (fig. 4).

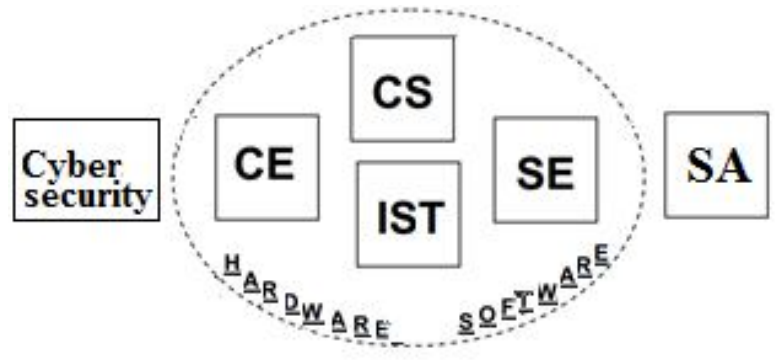

Fig. 4. Interrelation between IT specialties according to Ukrainian standards

Discussions about disagreements, differences and uniqueness of specialties in subject area "Information technologies" in Ukraine are continued.

Professional IT standards overview. Nowadays Ukrainian professional IT standards have been developed for the following professions: [19]

Information systems specialist;

Software developer;

Project manager in information technology;

Product manager in information technology;

Information resources specialist.

These standards are based on international information technology standards ISO / IEC 15288: 2008, ISO / IEC 12207: 2008, European Framework of Competences (e-CF) [20], [21], [22].

IT professions for which professional standards are developed in Ukraine correspond to nomenclature of professional profiles of European e-CF, namely: Information Systems Specialist, Software Developer, IT Project Manager, IT Product Manager, and Information Resources Specialist.

Professional standards operate with such concepts as: area of professional activity (functional area) is a group of similar professional activities which correspond to one or more economic activities.

type of professional activity is a set of generalized labor functions which are similar in nature, results and conditions of work;

generalized labor function is a set of related work functions, created by division of labor in a particular industrial (business) process;

labor function is a system of labor actions in the framework of generalized work function, which is defined by technological process;

labor action is the simplest manufacturing operation in the process of employees' interaction with the subject of labor, which results in achieving specific preliminary set goal;

employees' qualification is a measure of employees' professional training to perform specific type of work, which includes theoretical knowledge and practical skills that must comply with the Guide features of professional qualification;

level of qualification is a measure of professional skills within specific qualifications.

Professional standard "Information systems specialist" is considered next. Labor functions and labor actions are grouped in 15 functional areas. These functional areas correspond to lifecycle processes of information systems as per the standards ISO / IES 15288: 2008, ISO / IEC 12207: 2008 and e-CF descriptors of ICT competencies relevant to business processes in information systems (table 3): A. PLANNING (PLAN), B. IMPLEMENTATION (BUILD), C. START (RUN), D. ADAPTATION (ENABLE), E. MANAGEMENT (MANAGE) [22].

"Software developer" professional standard defines main purpose of professional activity namely development, debugging, testing, modification of software. Section "Requirements to education and training" defines qualification levels in accordance with the Sectoral Qualifications Framework (SQF) and provides list of educational levels required for obtaining certain qualification [23]. This professional standard defines tasks and qualification levels according to the functional areas of software developer as per the framework of competencies (Table 4).

Tasks are classified according to qualification levels, roles and job experience. The skill level according to the IT Industrial Qualifications Framework indicated for positions Junior Developer, Programming Technician, Programming Engineer, Senior Developer and Senior Programming Engineer.

\section{Conclusion}

The matter of harmonization of IT industry and IT education based on realization of effective mechanisms in social partnership is a main focus with a long term perspective. Interaction between IT industries and IT education is realized through the establishment of Educational Engineering Centers in Universities and Companies, to align scope and content of educational programs on some professional disciplines with employers, etc. 
Table 3. Correspondence between lifecycle processes, functional areas of information systems specialist professional standard and e-CF descriptors

\begin{tabular}{|c|c|c|c|c|}
\hline № & $\begin{array}{l}\text { Functional Area of } \\
\text { Professional } \\
\text { Standard }\end{array}$ & $\begin{array}{l}\text { Lifecycle Process } \\
\text { According to the ISO15288 }\end{array}$ & $\begin{array}{l}\text { ICT Competence } \\
\text { Descriptor According } \\
\text { to the e-CF }\end{array}$ & $\begin{array}{l}\text { ICT Competence According to } \\
\text { the e-CF }\end{array}$ \\
\hline 1 & $\begin{array}{l}\text { The Pre-contractual } \\
\text { Work }\end{array}$ & $\begin{array}{l}\text { Process of Life Cycle Model } \\
\text { Management }\end{array}$ & $\begin{array}{l}\text { A. Planning } \\
\text { E. Management }\end{array}$ & $\begin{array}{l}\text { A3. Development of business } \\
\text { plans } \\
\text { E1. Development of forecasts }\end{array}$ \\
\hline 2 & $\begin{array}{l}\text { Management of } \\
\text { Requirements }\end{array}$ & $\begin{array}{l}\text { The processes of definition of } \\
\text { holder's requirements and ana- } \\
\text { lysis of system requirements }\end{array}$ & A. Planning & $\begin{array}{l}\text { A2. Management of the service } \\
\text { level }\end{array}$ \\
\hline 3 & Customer Support & & C. Start & C1. Customer support \\
\hline 4 & Human Resources & $\begin{array}{l}\text { Human resources } \\
\text { management process }\end{array}$ & D. Adaptation & $\begin{array}{l}\text { D3. Organization of studies } \\
\text { D9. Staff training }\end{array}$ \\
\hline 5 & $\begin{array}{l}\text { Modeling of the } \\
\text { Customers' Business } \\
\text { Processes }\end{array}$ & $\begin{array}{l}\text { Process of Life Cycle Model } \\
\text { Management }\end{array}$ & A. Planning & $\begin{array}{l}\text { A1. Reconciliation of IS and } \\
\text { business strategy }\end{array}$ \\
\hline 6 & $\begin{array}{l}\text { Communications } \\
\text { Management }\end{array}$ & $\begin{array}{l}\text { Information management } \\
\text { process }\end{array}$ & $\begin{array}{l}\text { D. Adaptation } \\
\text { E. Management }\end{array}$ & $\begin{array}{l}\text { D10. Information and } \\
\text { knowledge management } \\
\text { E4. Relationship Management }\end{array}$ \\
\hline 7 & $\begin{array}{l}\text { Procurement } \\
\text { Management }\end{array}$ & $\begin{array}{l}\text { Purchasing and supply } \\
\text { processes }\end{array}$ & D. Adaptation & $\begin{array}{l}\text { D4. Ensuring of the } \\
\text { procurement process }\end{array}$ \\
\hline 8 & $\begin{array}{l}\text { Management of } \\
\text { contractual relations }\end{array}$ & $\begin{array}{l}\text { Portfolio management } \\
\text { processes }\end{array}$ & D. Adaptation & D8. Contract Management \\
\hline 9 & Development Process & $\begin{array}{l}\text { The processes of designing } \\
\text { the system's architecture, } \\
\text { implementation, integration, } \\
\text { qualification testing. }\end{array}$ & $\begin{array}{l}\text { A. Planning } \\
\text { B. Implementation }\end{array}$ & $\begin{array}{l}\text { A5. Designing architecture } \\
\text { A6. Applications' development } \\
\text { B2. Systems' integration } \\
\text { B3. Testing }\end{array}$ \\
\hline 10 & Quality Assurance & $\begin{array}{l}\text { Process of Quality } \\
\text { Assurance }\end{array}$ & $\begin{array}{l}\text { D. Adaptation } \\
\text { E. Management }\end{array}$ & $\begin{array}{l}\text { D2. Development of IS Quality } \\
\text { Assurance Strategy } \\
\text { E6. IS Quality Management }\end{array}$ \\
\hline 11 & $\begin{array}{l}\text { Configuration } \\
\text { Management }\end{array}$ & $\begin{array}{l}\text { Configuration management } \\
\text { process }\end{array}$ & & \\
\hline 12 & $\begin{array}{l}\text { Deployment/ } \\
\text { Implementation of IS }\end{array}$ & $\begin{array}{l}\text { The installation and support } \\
\text { of software, support of } \\
\text { software acceptance and } \\
\text { functioning }\end{array}$ & $\begin{array}{l}\text { A. Planning } \\
\text { B. Implementation }\end{array}$ & $\begin{array}{l}\text { A7. Introduction of technologies } \\
\text { B1. Design and Development } \\
\text { B4. Solutions' Deployment }\end{array}$ \\
\hline 13 & $\begin{array}{l}\text { Management of } \\
\text { Changes }\end{array}$ & Software revision process & $\begin{array}{l}\text { C. Start } \\
\text { E. Management }\end{array}$ & $\begin{array}{l}\text { C2. Changes Support } \\
\text { E5. Improvement of processes } \\
\text { E7. Management of Changes }\end{array}$ \\
\hline 14 & $\begin{array}{l}\text { Document } \\
\text { Management }\end{array}$ & $\begin{array}{l}\text { Document management } \\
\text { process }\end{array}$ & B. Implementation & $\begin{array}{l}\text { B5. Development of the } \\
\text { documentation }\end{array}$ \\
\hline 15 & $\begin{array}{l}\text { Security } \\
\text { Management }\end{array}$ & Risk Management Process & $\begin{array}{l}\text { C. Start } \\
\text { D. Adaptation } \\
\text { E. Management }\end{array}$ & $\begin{array}{l}\text { C4. Problem's management } \\
\text { D1. Development of } \\
\text { Information security strategy } \\
\text { E3. Risk Management } \\
\text { E8. Information security } \\
\text { management }\end{array}$ \\
\hline
\end{tabular}

\section{Table 4. Functional areas, tasks and qualification levels in software developer professional standard}

\begin{tabular}{|c|c|c|c|c|c|c|c|}
\hline \multirow{2}{*}{$\begin{array}{l}\text { Functional } \\
\text { areas }\end{array}$} & \multirow[t]{2}{*}{ e-CF Descriptors } & \multirow[t]{2}{*}{ Tasks } & \multicolumn{5}{|c|}{$\begin{array}{l}\text { The skill level according to the IT } \\
\text { Industrial Qualifications Framework }\end{array}$} \\
\hline & & & 1 & 2 & 3 & 4 & 5 \\
\hline \multirow[t]{9}{*}{$\begin{array}{l}\text { Management of } \\
\text { system development }\end{array}$} & $\begin{array}{l}\text { Manage / Business } \\
\text { Management }\end{array}$ & $\begin{array}{l}\text { Analysis of software } \\
\text { requirements }\end{array}$ & & & + & + & \\
\hline & Plan /Design & Design of system architecture & & & & + & + \\
\hline & Plan /Design & Design of software architecture & & & + & + & + \\
\hline & Build/Development & Detailed software design & & + & + & + & \\
\hline & Build/Development & Software development & + & + & + & & \\
\hline & Build/Development & Software complexing & & + & + & + & \\
\hline & Build/Development & Software qualification testing & + & + & + & & \\
\hline & Build/Development & System complexing & & + & + & + & \\
\hline & Build/Development & System qualification testing & & + & + & + & \\
\hline \multirow{2}{*}{\begin{tabular}{|l|} 
Deployment / \\
Implementation
\end{tabular}} & Run/Service\&Operation & Software installation & & + & + & + & \\
\hline & Run/Service\&Operation & Support of final testing & & + & + & + & \\
\hline $\begin{array}{l}\text { Support of } \\
\text { functioning }\end{array}$ & Enable/Support & Software maintenance & + & + & + & & \\
\hline
\end{tabular}


Methodological basis of educational standards in IT areas are Computing Curricula recommendations of IT associations and communities ACM, IEEE, AIS, AITP for specialties Computer Science, Computer Engineering,
Software Engineering, Information Systems \& Technologies. IT Professional standards define stakeholders' requirements to IT graduates' competencies which helps to improve higher education quality.

\section{REFERENCES}

1. Statystychnyy byuleten «Osnovni pokaznyky diyalnosti vyshchykh navchalnykh zakladiv Ukrayiny za 2016/17 navchalnyy $r i k\rangle$ [Statistical Bulletin "Key Performance Indicators of Ukraine's Higher Educational Institutions for 2016/17 academic year"], available at: http://www.ukrstat.gov.ua/druk/publicat/kat u/publosvita u.htm (last accessed March 01, 2018).

2. Verkhovna Rada Ukrayiny (2014, lypen 1). Zakon № 1556-VII, Pro vyshchu osvitu [Verkhovna Rada of Ukraine (July 1, 2014). Law No. 1556-VII, On Higher Education], available at: http://zakon5.rada.gov.ua/laws/show/1556-18 (last accessed March 01, 2018).

3. Tymchasove polozhennya pro orhanizatsiyu osvitnoho protsesu v KPI im. Ihorya Sikorskoho [Temporary position on the organization of the educational process in Igor Sikorsky KPI], available at http://kpi.ua/document programm (last accessed March 01, 2018).

4. Postanova Kabineta Ministriv Ukrayiny (23 lystopada 2011). № 1341 Pro zatverdzhennya Natsionalnoyi ramky kvalifikatsiy [Decree of the Cabinet of Ministers of Ukraine (November 23, 2011) No. 1341 On Approval of the National Qualifications Framework], available at http://zakon2.rada.gov.ua/laws/show/1341-2011-\%D0\%BF/paran12\#n12 (last accessed March 01, 2018).

5. Computing Curricula 2001 Computer Science, available at https:/www.acm.org/binaries/content/assets/education/curricularecommendations/cc2001.pdf (last accessed March 01, 2018).

6. Computing Curricula 2005. The Overview Report, available at https:/www.acm.org/binaries/content/assets/education/ curricula-recommendations/cc2005-march06final.pdf (last accessed March 01, 2018).

7. Information Technology 2008, available at https://www.acm.org/binaries/content/assets/education/curricularecommendations/it2008-curriculum.pdf (last accessed March 01, 2018).

8. Curriculum Guidelines for Undergraduate Degree Programs in Information Systems 2010, available at https:/www.acm.org/binaries/content/assets/education/curricula-recommendations/is-2010-acm-final.pdf (last accessed March 01, 2018).

9. Computer Science Curricula 2013, available at https://www.acm.org/binaries/content/assets/education/cs2013_web final.pdf (last accessed March 01, 2018).

10. Software Engineering 2014, available at https:/www.acm.org/binaries/content/assets/education/se2014.pdf (last accessed March 01, 2018).

11. Computer Engineering Curricula 2016, available at https://www.acm.org/binaries/content/assets/education/ce2016-finalreport.pdf (last accessed March 01, 2018).

12. MSIS 2016 Global Competency Model for Graduate Degree Programs in Information Systems, available at https://www.acm.org/binaries/content/assets/education/msis2016.pdf (last accessed March 01, 2018).

13. Cybersecurity Curricula 2017, available at https://www.acm.org/binaries/content/assets/education/curricularecommendations/csec2017.pdf (last accessed March 01, 2018).

14. Information Technology Curricula 2017, available at https://www.acm.org/binaries/content/assets/education/curricularecommendations/it2017.pdf (last accessed March 01, 2018).

15. Profesiinyi standart Fakhivtsia $z$ informatsiinykh system [Professional standards of Information Systems Specialist], available at https://mon.gov.ua/storage/app/media/vyshcha/IT-prof-standarty/5-ps-spes-infosystems-13.12.2014.pdf (last accessed March 01, 2018).

16. Proekt standartu Vyshchoi osvity "Kompiuterni nauky ta informatsiini tekhnolohii", bakalavr [Project of educational standard "122 Computer Science and Information Technologies", bachelor], available at http://mon.gov.ua/activity/education/reforma-osviti/naukovo-metodichna-rada-ministerstva/proekti-standartiv-vishhoyiosviti.html (last accessed March 01, 2018).

17. Postanova Kabinetu Ministriv Ukrayiny (1 lyutoho 2017). № 53 Pro vnesennya zmin do postanovy Kabinetu Ministriv Ukrayiny vid 29 kvitnya 2015 № 266 [ Decree of Cabinet of Ministers of Ukraine (February 1, 2017) № 53 On Amendments to the Decree of Cabinet of Ministers of Ukraine on April 29, 2015, No. 266], available at https://www.kmu.gov.ua/ua/npas/249722170 (last accessed March 01, 2018).

18. Nakaz Ministerstva osvity i nauky Ukrayiny vid «01» chervnya 2017 № 600 Metodychni rekomendatsiyi shchodo rozroblennya standartiv vyshchoyi osvity [Order of the Ministry of Education and Science of Ukraine on June 01, 2017 No. 600 Guidelines on the development of higher education standards], available at https://mon.gov.ua/storage/app/media/vishcha-osvita/rekomendatsii-1648.pdf (last accessed March 01, 2018).

19. Profesiyni Standarty [Professional Standards], available at https://mon.gov.ua/ua/osvita/visha-osvita/suchasna-it-osvita-vukrayini/profesijni-standarti (last accessed March 01, 2018).

20. Systems and software engineering - System life cycle processes. International Standard ISO/IEC 15288 - IEEE Std 152882008, available at http://marte.aslab.upm.es/redmine/files/dmsf/p asys-eggineering-methodolgy/150325093527 52 ISOIEC-IEEE 15288-2008.pdf (last accessed March 01, 2018).

21. ISO/IEC 12207:2008 - IEEE Std 12207-2008 Systems and Software Engineering - Software Life Cycle Processes, available at https://pdfs.semanticscholar.org/presentation/1806/1ac358b6dff0d58422fa6eaa781e0283f351.pdf (last accessed March 01, 2018).

22. European ICT Professional Profiles, available at ftp://ftp.cen.eu/CEN/Sectors/List/ICT/CWAs/CWA\%2016458.pdf (last accessed March 01, 2018). 
23. Profesiinyi standart Fakhivtsia z rozrobky prohramnoho zabezpechennia [Professional standards of Software Developer Specialist], available at https://mon.gov.ua/storage/app/media/vyshcha/IT-prof-standarty/6-ps-rozrobnik-pz-13.12.2014.pdf (last accessed March 01, 2018).

Надійшла (received) 22.03.2018

Прийнята до друку (accepted for publication) 23.05.2018

\section{Освітні програми та професійні стандарти в IT галузі як фактор розвитку IT освіти}

\section{Т. В. Ковалюк, О. А. Чайковська}

Предметом вивчення в статті $є$ питання взаємодії ІТ-освіти та IT-індустрії через зв'язок освітніх і професійних IT-стандартів. Метою є розгляд необхідності, ролі та основних понять освітніх і професійних IT-стандартів у системі ITіндустрія - IT-освіта, визначення складу нормативної бази змісту вищої освіти України та місця в ній професійних та освітніх стандартів. Завдання: показати, що модернізація вищої комп’ютерної освіти має відбуватися 3 урахуванням вимог роботодавців, для формалізації яких застосовуються професійні ІТ-стандарти. Описати структуру та зміст професійних IT-стандартів в Україні. Довести, що професійні стандарти забезпечують сферу освіти необхідною інформацією про області та об'єкти професійної діяльності випускників, їх види, завдання та необхідні компетенції майбутніх фахівців. Використовуваними методами $є$ аналіз нормативної бази змісту вищої освіти України, міжнародних документів Computing Curricula та Європейської рамки IКТ-компетентностей, функціональних галузей, задач діяльності та кваліфікаційних рівнів; опитування роботодавців з метою визначення вимог, що є підставою для визначення компетентностей випускників IT-спеціальностей вищих навчальних закладів. Результати. В статті поданий порівняльний аналіз особливостей освітніх ІТ-стандартів за шістьма ІТ-спеціальностями галузі знань «Інформаційні технології». Проаналізований взаємозв'язок IT-спеціальностей через аналіз об'єктів діяльності та теоретичного змісту предметних галузей, що описані в освітніх стандартів. Визначене місце кожної із IT-спеціальності в системі IT підготовки бакалаврів. Описана особливість відтворення рекомендацій Computing Curricula в українських IT-стандартах. Висновки. У статті показано, що методологічною основою системи освітніх IT-стандартів України є міжнародні документи Computing Curricula та Європейська рамка ІКТ-компетентностей. На прикладі професійного стандарту фахівця 3 інформаційних технологій розглянуто його зв'язок із дескрипторами Європейської рамки ІКТкомпетентностей. Аналіз функціональних галузей, задач діяльності та рівнів кваліфікацій, що подані у професійному стандарті розробника програмного забезпечення, визначає зміст підготовки фахівців з розробки та тестування програмного забезпечення. Визначення професійних компетентностей в освітніх стандартах на підставі вимог роботодавців та кваліфікаційних рівнів актуалізує освітні стандарти відповідно до вимог ринку праці. Така гармонізація підготовки робить українських ІТ фахівців конкурентоспроможними із їх закордонними колегами.

Ключов і слов а: IT-індустрія; IT-освіта; професійні стандарти; освітні стандарти; компетентності.

\section{Образовательные программы и профессиональные стандарты в IT отрасли как фактор развития IT образования}

\section{Т. В. Ковалюк, Е. А. Чайковская}

Предметом изучения в статье является вопрос взаимодействия IT-образования и IT-индустрии за связь образовательных и профессиональных ІТ-стандартов. Целью является рассмотрение необходимости, роли и основных понятий образовательных и профессиональных IT-стандартов в системе IT-индустрия - IT-образование, определение состава нормативной базы содержания высшего образования Украины и места в ней профессиональных и образовательных стандартов. Задания. Показать, что модернизация высшего компьютерного образования должна происходить с учетом требований работодателей, для формализации которых применяются профессиональные ITстандарты. Описать структуру и содержание профессиональных ІТ-стандартов в Украине. Доказать, что профессиональные стандарты обеспечивают сферу образования необходимой информацией об областях и объектах профессиональной деятельности выпускников, их виды, задачи и необходимые компетенции будущих специалистов. Используемыми методами являются анализ нормативной базы содержания высшего образования Украины, международных документов Computing Curricula и Европейской рамки ИКТ-компетентностей, функциональных областей, задач деятельности и квалификационных уровней; опрос работодателей с целью определения требований, которые является основанием для определения компетенций выпускников IT-специальностей высших учебных заведений. Результаты. В статье представлен сравнительный анализ особенностей образовательных IT-стандартов по шести IT-специальностям отрасли знаний «Информационные технологии». Проанализирована взаимосвязь ITспециальностей через анализ объектов деятельности и теоретическое содержание предметных областей, описанных в образовательных стандартах. Определено место каждой из IT-специальностей в системе IT подготовки бакалавров. Описана особенность воспроизведения рекомендаций Computing Curricula в украинских IT-стандартах. Выводы. В статье показано, что методологической основой системы образовательных IT-стандартов Украины являются международные документы Computing Curricula и Европейская рамка ИКТ-компетенций. На примере профессионального стандарта специалиста по информационным технологиям рассмотрены его связь с дескрипторами Европейской рамки ИКТ-компетенций. Анализ функциональных областей, задач деятельности и уровней квалификаций, представленный в профессиональном стандарте разработчика программного обеспечения, определяет содержание подготовки специалистов по разработке и тестированию программного обеспечения. Определение профессиональных компетенций в образовательных стандартах на основании требований работодателей и квалификационных уровней актуализирует образовательные стандарты в соответствии с требованиями рынка труда. Такая гармонизация подготовки делает украинских IT специалистов конкурентоспособными с их зарубежными коллегами.

Ключевые слов а : ІТ-индустрия; IT-образование; профессиональные стандарты; образовательные стандарты; компетентности. 